\title{
Existential Crisis, Sexuality and Immutable Plight of Women in the Plays 'Sakharam Binder' and 'Silence the Court is in Session'
}

\author{
Shehnaz Khan \\ PhD Research Scholar \\ Jiwaji University \\ Gwalior, Madhya Pradesh, India \\ khanaishnaaz@gmail.com
}

\begin{abstract}
“It's a men's world women are here only to assist, serve and please men. It's the way the world has always been."
\end{abstract}

In the world there is only one supreme culture prevailing universally in all the societies is the men-centric culture, which is all powerful and all pervasive. This patriarchal culture and its norms are so deeply engrained in the soul of people that they relegate women into fringe or secondary position.

Women's rights talk about equality in each aspects of life but in India where patriarchy has solid roots in society, it appears to be extremely hard to acquire concordance and equality in power structures. Patriarchy has clasped Indian middle class society in its stereotyped shackles and its hold on society is unbending and heavy which adversely affects the lives of women. The torture born by women is the result of brutal dominating tendency of males and Tendulkar in general, spotlights on the patriarchal society in both of his plays. He indicated how a men centric society and women's liberation are interconnected and how male domination transforms into maltreatment of women. All the power in Indian society is in the hands of the males which at last prompts the pathetic state of females. Power, when gets 
discordant, without a doubt results into persecution and domination whether it is mastery of man over women or the other way around. Indian middle class has the same imbalanced power structure and consequently male domination exists because of male dominated society. The ruling idea of males tosses women into a well of persecution of each sort. Such state of females is exhibited by Tendulkar in 'Sakharam Binder' and in 'Silence the Court is in Session' caused by the patriarchal system of culture wherein the women have to struggle hard and pass through severe plight to establish their place in society. As we see in case of these three women Miss Benare, Laxmi and Champa. All these three are discarded women who strive hard for their existence in society and have to pass through so many inextricable difficulties. But the plight goes immutable, and unending.

Keywords: Immutable, Transitory Spouses, Oppression, Patriarchy, Struggle For Existence, Torment, Capitulate

The play 'Sakharam Binder' begins when Sakharam takes Laxmi, the seventh lady, home to fulfil every single need including his carnal desires. Laxmi is depicted as a decent and religious lady who has faith in God, but the manner in which she worships her better half demonstrates her to be a victim of male commanded society. She has faith in social codes and traditions. In spite of the fact that, she is displayed as a decent lady and a great spouse, yet she can't escape from being exploited by the society. She is relinquished by her husband because of her barrenness. This shows the cruelty of male-dominated society. In patriarchal society, women are oppressed for not satisfying their spouses' wishes and desires.

Meenakumari strongly agrees with Tendulkar when she states: 
"Indian Civilization has an unquestioned practice of treating women as the secondary self who has to dance to the tune of man's lyric as regards their choice, belief and life style.... In patriarchal culture, power is equated with aggression and masculinity, weakness with compassion and feminity. Women are supposed to bear male oppression silently and meekly." (140)

The harsh thing that Tendulkar displays in this play is that the exploited women don't blame their better halves for their destitution; they see themselves as the one responsible for this uncouth treatment. They even think that their spouses have the privilege to rebuff them if they can't satisfy their husbands' desires. A similar treatment can be found in the life of Laxmi, who is first tortured and oppressed by her own better half and later by Sakharam. He beats her in any event, for not giggling on his interest. Tendulkar shows passive frame of mind of Laxmi towards her sufferings and her compliant nature to the male-centric culture.

As Sakharam doesn't have faith in the foundation of marriage. Hence, he stays unmarried throughout his life. However, he offers haven to a vulnerable, forsaken woman in the society not with the goal of improving her life but to abusing her further by fulfilling his sexual want. It is a sort of legally binding relationship dependent on common accommodation. Wine and women are his main attractions. He has his own guidelines of the game, an exceptional good code, which he anticipates that his brief time woman should maintain. In a series, he brings Laxmi to his home, the seventh one in the arrangement of his women or 'transitory spouses'.

Sakharam's relationship with Laxmi realizes some great changes in his way of life. He turns out to be sincerely strict, cleans up, and changes himself into a capable 'family man'. He himself sees these progressions happening in him but neglects to ascribe the credit to Laxmi. After her departure he admits sincerely: 
"There have been many women here, but this one left a mark before she went away.” (P.153)

After Laxmi's departure Sakharam brought Champa, the police Faujdar Shinde's wife, into his home. A foil to Laxmi, she is more youthful, somewhat plumper, and better fabricated. Ostensibly, Sakharam imagines that he is a friend in need of women, but deep down he is a dumping ground of all that is awful in the society, so far as man-woman relationship is concerned. Despite the fact that he condemns wedded life, he grows such a relationship, which is more terrible for the woman who endures more with Sakharam than with her husband previously. What's more, he is prepared to toss her out when there remains nothing womanly about her. Consequently, E. Renuka is very right in pointing out that "Sakharam's temperament is as misleading as that of a crocodile. Although he comprehends and bolsters a defiant lady, he needs his woman to slave for him day and night, to regard his wishes, and to fulfil his desire. He professes to be the rescuer of ladies by offering them an actual existence superior to the prior one, however he is neither a friend in need, nor a radical, but a licentious, a conceited pleasure seeker."

Shockingly enough, inspite of knowing Sakharam to be a womanizer, Laxmi never sets out to challenge the lusty exercises done to her. Indeed, even Sakharam disallows her dozing at night to fulfil his own yearning and uses her as a toy-

"No, you can sleep later. Get up and laugh .laugh or I'll choke the life out of you. Laugh! Laugh! Go on, Laugh!” [Act-I, pg-141]

After Laxmi's departure Sakharam brought Champa, the police Faujdar Shinde's wife, into his home. A foil to Laxmi, she is more youthful, somewhat plumper, and better fabricated.Champa, despite what might be expected, resembles a beguiling character equipped for drawing in men like Sakharam and Dawood. Truth be told, she practices her 
solid impact so as much that he neglects to rule her. He is so much physically pulled in towards her that he couldn't focus on his day's work and satisfies each of her demands like an obeyed worker. He carries tea for her and hurries to make courses of action for supper. Indeed, even Dawood is stupefied when "she smiles bewitchingly at him". [Act-II, pg-160] and later on develops an illicit relation with her at his friend's back. Indeed, even the regard which he provides for Laxmi by calling her 'Bhabhi' is missing here as he treats Champa as a 'sexual commodity'.Champa's betrayed spouse pursues her to Sakharam's house with a want to take her back not on the grounds that he needed her in his life as a devoted wifebut as an object of flesh and blood who is fit for fulfilling his bodily want. Champa's sex appeal is such inebriating that inspite of her forceful state of mind towards her better half, the latter urges her -

"Kill me Champa... open the door. I'm here. Why don't you beat me, Champa?" [Act-III, pg-198]

Sakharam is an utter slave for his lustful feelings, that is not satisfied completely by Laxmi as she never participated freely in sex due to somewhat her submissive, and coy nature.

With the arrival of champa, the second lady Sakharam can satisfy his sexuality. He changes into a sensuous, lewd boozer with considerations of just sexual delight. Champa looks enticing, who has deserted her indecent yet inept spouse.Champa is a sexual challenge to Sakharam. He is attracted by her body while talking about rules of the house, he controls a ton to liberate himself from the attraction of her body.

At first Sakharam is completely lost in her erotic body. He can't focus on his work and used to come ahead of schedule from his work. He brings alcohol which makes her weak and she submits to Sakharam. Sakharam even quits going to press and Dawood convinces him to carry out his responsibility consistently. But, on this Sakharam says: 
"I grew up like a cactus - out in the open. I don't scare easy. From now on it is going to be Champa, Champa nothing more.... nobody can match her little finger. you don't know what fun Champa is." (pp.172-173)

Champa on the other hand reminds Sakharam of his being impotence due to the presence of Laxmi, she insultingly says to him:

"Stop that Champa -Champa'- you're not a man - not since she came. She's made an impotent ninny of you. Don't have the guts to take me before her. You turn into a corpse- a worm."(p.193)

Having realised of all this happening because of Laxmi's presence, he furiously comes out of his room and tells her-

"leave this house. This very minute. She says you have made a ninny out of me. You beggar." (p.194)

Terrorizes with the brutal behaviour of Sakharam, desperate laxmi plays her trump card by revealing Sakharam, Champa's liaison with Dawood the other day,

"It's true- it's the truth- these lips have never spoken a lie yet-she's unfaithful to you -yes- with Dawood. She goes to him -every afternoon - when you're at the press. I've seen them -with my own eyes." (p.196)

Having been known about Champa's illicit relationship with Dawood and his being impotent Sakharam's masculinity is doubly hurt,he can't hold up under this. His male inner self disallows him to absolve her and thus he executes her in an attack of furore.

Maybe so as to escape from this claustrophobia, and to have her own will, she catches with Dawood and thus finds a brief alleviation from her torments. Hence, inspite of her beguiling character, Champa turns into a victim of the distorted man centric culture and pays for her free will or of her indecency. She is mercilessly killed by Sakharam out of doubt. 
Laxmi was also struggling for her existence when re-entered into the life of Sakharam just to change it. At first she has all the earmarks of being compliant, tame, meek and defenceless lady, a normal 'angel in the house'who never sets out to apply her will over Sakharam. Her returning back to Sakharam likewise shows her adoration and commitment towards him other than her weakness of being shelter less. She is even prepared to bargain with Champa when the later says -

"Stay. You look after the house, I"lllook after him." [Act-III, pg-181]

Be that as it may, what the established truth is by all accounts is that Laxmi had as of now in her a shrouded aspiration of controlling others and to appreciate a free life-a real existence which will stream as indicated by her very own will and of which she is constantly denied. Her respecting the Patriarchal society made her compliant up until this point. Also, presently she thinks that its painful to impart her mate to the other lady who has interrupted into their 'happy life'. Her chance comes when she happens to think about Champa's affair with Dawood.

In this manner out of sheer desire and a desire to have her mate and accordingly recapture her throne, she retaliates upon Champa who once protected her, by planting the seed of doubt inside Sakharam and impelling him to punishher for her sins. Being obsequious with the emotion of love and dignity towards Sakharam Laxmi regards him as her husband and God and hence tolerates his tyrannical behaviour by obeying each of his commands submissively on the other hand we see in her the servility towards subtle violence that makes us shocked. Apparently she seems to be a symbol of grave, perfect spouse, who complies with each instruction of Sakharam. Be that as it may, towards the finish of the play she displays the natural brutality of her character. Sakharam gets confounded in the wake of executing champa, however Lakshmi sooths him. For her it's not a killing but Sakharam had done a divine act by murdering a sinner. Lakshmi who shows up all through the play as an 
exemplification of virtues, onlooker of ethical quality doesn't discover Sakharam's go about as a wrongdoing. However, the fact is that, it is she who energizes him to kill her. The dead body of Champa doesn't frighten her, rather she herself starts digging the grave for champa and proposes to him to bury her. Sakharam who has been showing up exceptionally vicious and striking got panicked and Lakshmi attempts to comfort him by saying:

"She was unfaithful to you. You are a good man . God will forgive you. "(p.197).

“Anyway she was a sinner. . She'll go to hell. Not you. I've been a virtuous woman . My virtuous deeds will see both of us through. I'll stay with you. I'll look after you. $"(P .196)$

Vijay Tendulkar hence appears to display the two female heroes in another light which urges us to uncover the shrouded privileged insights of a ladylike substance and furthermore causes us to understand their dilemmas in the male dominated society. Moreover, he appears to feature the Darwinian idea of the struggle for existence which empowered Laxmi to battle for her privileges and in this way become the fittest to survive. But her pitiful life is never going to be end. The same pitiful, torturous life of Miss Benare is presented in the next play of Tendulkar.

Tendulkar's 'Silence! The Court Is In Session' is an investigation on the silence of women in the patriarchal system of society. Women are explicitly sexually exploited and our Indian culture has subjugated women for a long time while men are allowed to have relationship inside and outside the marriage but the women are expected to carry the load of so-called societal norms and values alone on their shoulders which impedes their free will to lead their life in their way, since they are tied down tightly in these shackles while men are free to practice unlawful things. This is an irony of women's life which is shown in this play by Tendulkar which puts bondage on their freedom. In this connection, Simon de Beauvoir says in her book 'Second Sex' 
"The advantage man enjoys and which manifests itself from childhood onward is that his vocation as a human being in no way contradicts his destiny as a male. However for women to accomplish her femininity she is required to be an object and prey”

In the play 'Silence! The court is in session', there is a mock-trial which is contrived on Benare to disclose her own life. The male chauvinists try to pull her down by dismembering her private issues and she is seriously tormented. All men in the play Sukhatme, Ponkshe, Rokde, Karnik, and Mr., Mrs. Kashikar are incomplete and fail in their profession and in life but very zealously, relishingly are dissecting the life of Miss Benare.

In the practice of the mock trial, they make Miss Benare, the accused of the wrongdoing of child murder. First and foremost, everything is by all accounts happy but later it turns out to be very brutal that Miss Benare is intentionally focused on. She was closed up in the trial room deliberately so that there will never be a way out for her even in her life. Benare, before setting up the trial, is cautioned to be quiet while others do the dissection of her own life.

Continuously these men for the sake of arraignment put negative shades on Benare's character. As she is unmarried in her 30's they mean that she is running behind each man constantly. It's exceptionally shocking that Mrs. Kashikar despite being a woman is unable to feel the pain and suffering of a lonely miserable woman, isn't reasonable at all as a woman and causes men to maintain it. Miss Benare requests them not to discuss her own life in the fake trial but men were particularly intrigued and getting a relish out of it.

Whatever she expresses in her defence and tries to clarify her situation, everything is taken in a negative sense. The observers give the indication that she was seen alone with Professor Damle in his room and the discussion among Damle and Benare is portrayed. 
Benare shouts out, "You've all deliberately ganged up on me! You've plotted against me!" (93).

Kashikar Says "Our society should receive the old custom of child marriage. Marry off the girls before puberty. All this promiscuity will come to a full stop." (98)

Mrs. Kashikar blames of all the calamity befell on Benare because of her doing a job which has made her like that as she has got a lot of liberty and because of her being unmarried, she moves openly with men.

In this connection, Simon de Beauvoir says"....her wings are cut and then she is blamed for not knowing how to fly."

Benare is seen as blameworthy of child murder and a verdict is issued to condemn her. She is an unmarried woman and has conceived the child out of wedlock and her conscience has been messed up for her transgression. The man behind this transgression isn't blamed for anything who keeps an equal part in this sin. Regardless of whether it is an assault on a child having conceived by an unmarried woman, it is only the woman who is focused on and tormented and made to feel guilty. Tendulkar addresses this deduction in the society why just a woman alone needs to confront this kind of attack and capitulate peacefully.Nana Saheb Shinde the administrator of the education society had decided to dismiss Benare from the school. He says,

"It is a sin to be pregnant before marriage. It would be still more immoral to let such a woman teach, in such a condition!” (113).

Sukhatme in his arraignment says Benare has made a disgusting crime she is improper and raising the offspring of an illicit association is much more horrible.

Sukhatme while levelling the charge against Miss Benare:

"Milord, the nature of the charge against the accused, Miss Leela Benare, is truly dreadful. The woman who is accused has made a heinous blot on the sacred blow of 
motherhood-which is purer than heaven itself....Her conduct has blackened all social and moral values...if such socially destructive tendencies are encouraged to flourish, this country and its culture will be totally destroyed....The charge against the accused is one of infanticide. But the accused has committed a far more serious crime. I mean unmarried motherhood. Motherhood without marriage has always been considered a very great sin by our religion and our traditions.......Milord, infanticide is a dreadful act. But bringing up the child of an illegal union is certainly more horrifying. If it is encouraged, there will be no such thing as the institution of marriage left. Immorality will flourish. Before our eyes, our beautiful dream of a society governed by tradition will crumble into dust... Woman bears the grave responsibility of building up the high values of society. Na striswatantryamarhati. 'Woman is not fit for independence.... With the urgent plea that the court should show no mercy to the accused, but give her the greatest and severest punishment for her terrible crime...."(Tendulkar 1967:115)

Here the male centric social framework prescribes the way and examples for women but couldn't care less about the men's deeds. This methodology just aggravates the gender discrimination in the society.

Again in this play Tendulkar expresses his view that women, according to man, isn't more than the 'body'; she is adored as goddess in myths and customs but in reality she doesn't have a will of her own; has no privilege on her feelings; has no identity of her own to choose, to act or even to think and to love. If she goes against this bad-to-the-bone truth of the male centric culture she is rebuffed, oppressed and underestimated as victim. This cruel circumstance of Indian culture is reflected impeccably when misled Miss Benare, breaks down to express a great deal to the men throughout her life and to the society on the loose: 
"Again, I fall in love. As a grown woman, I threw all my heart into it ; I thought, this will be different. This love is intelligent. It is love for an unusual intellect. It isn't love at all-its worship. And my intellectual god took the offering - and went his way. He didn't want my mind, or my devotion - he didn't care about them ! [Feebly.] He wasn't a god. He was a man. For whom everything was of the body, for the body! That's all. Again, the body! [Screaming.] This body is a traitor!" (Tendulkar 1967:118)

Along these lines through this expression plainly one can understand woman is socially moulded in such a way that she can't overrule the social standards made for her by the male controlled society; even her body is controlled to make her vibe that she is set optional in the society; and she doesn't have any privilege on her body; if she crosses the limit she is rebuffed; in the expressions of Kashikar:

Further he says, "Neither you nor anyone else should ever do anything like this again. No moment of your sin should remain for future generations. Therefore this court hereby sentences that you shall live. But the child in your womb shall be destroyed"(119).

Benare cries out" No!No!No! - I won't let you do Kashikar, assuming the job of the Judge in the mock trial insists the social control on the women by saying:

"Prisoner Miss Benare, play the closest attention. Your sin must be expiated. Irresponsibility must be chained down, Social customs, after all, are of supreme importance. Marriage is very foundation our society's stability. it - I won't let it happen - I won't let it happen!'(119). Thus the mock trial is over.

Motherhood must be sacred and pure. This court takes a serious view of your attempt to dynamite all this.....And what is more, the arrogance with which you 
conducted yourself in the society, having done all these things, that arrogance is the most unforgivable thing of all. The morality which have shown through your conduct was the morality you were planning to impart to the youth of tomorrow..... Hence not only today's but tomorrow's society would have been endangered by your misconduct . By the grace of God, it has all been stopped in time." (Tendulkar 1967:118-119)

In evident sense this play of Tendulkar appears to be ready to voice the unheard cryings and outcries of women that are constantly kept in the background: 'from some place inconspicuous, her very own voice is heard singing delicately.'

"And the wound that's born to bleed

Bleeds on forever, faithfully

There is a battle sometimes, where

Defeat is destined as the end.

Some experiences are meant

To taste, then just to waste and spend"

Here through this song Miss Leela Benare expresses not only her very own energy to live completely and pursue the fantasies of her own but additionally the yearnings of Indian women to confront the world and its difficulties, regardless of knowing the results.

The most striking fact in this trial is the silence of the person who is being accused. Benare holds fast to quiet and it indicates her enslavement and weakness. She is compelled to acknowledge her wrongdoing and the co-accomplice in the wrongdoing is left set free. That is the manner in which the society is structured for men to control women. Simone De Beauvoir properly cites,

"Representation of the world, like the world itself, is the work of men; they describe it from their own point of View, which they confuse with absolute truth". 
The double faced views of the society are all around described through the expressions of Benare,

"Their lips are full of lovely worn-out phrases! And, their bellies are full of unsatisfied desires"(117).

Benare is educated, straightforward, and independent and free reasoning. She is a woman so her independent way of driving life is objected. Tendulkar is denouncing the supposed modern society which likes about everything and as a general rule chokes out women's free will of living. Just Benare is expelled from her teaching work scrutinizing her ethical quality however Mr.Damle is having unlawful connection with a woman though wedded is allowed to continue as a professor.

Thus victim Benare is capitulated to power and felt being smothered severely under the wall of the male centric hypocrisy.

Being distraught and shattered with all the allegations and court verdict Benare says: "Life isn't worthy of life" (Tendulkar 73). She addresses the motivation behind life concerning why people talk about optimism and don't focus on the troubles and problems of others. What she has experienced is overlooked and made a victim of the wrongdoing she accidently committed."

In the peak, Benare conveys a splendid monologue that unravelled the false notions of the male chauvinist. She portrays her account of depression and forlornness, her situation of freedom and servitude, and her story of a love hate relationship with life. Leela Benare's monologue of self-protection shows her mental trauma. During the court procedures, the judge's cry of 'silence' suffocates her fights on a few events.

Sparrows are illustrative of Benare herself, and all the more explicitly of the annihilation she feels at the possibility of losing her kid and her job. Twice in the play Benare 
sings a similar tune including the bird, apparently one she learned as a kid and now sings to her students. The full melody goes,

"The parrot to the sparrow said, 'Why, oh why, are your eyes so red?' 'Oh, my dear friend, what shall I say? Someone has stolen my nest away.' Sparrow, sparrow, poor little sparrow... 'Oh, brother crow, oh, brother crow, Were you there? Did you see it go?' 'No, I don't know. I didn't see. What are your troubles to do with me?' $O$ sparrow, sparrow, poor little sparrow."

The tune expressly maps the trouble of Benare's life. Like the sparrow, quite a bitter of her security (or home) has been taken from her; Benare now has lost her job and has minimal possibility of finding a spouse. Moreover, during the trial when Mr. Kashikar gives verdict that she should end her pregnancy. In spite of the fact, that this trial has no real lawful grounds. The thought of her unborn kid's life in peril damages Benare and further mirrors the taking of the sparrow's home.

Tendulkar, through his plays, criticizes the way that the destiny of all women is for the most part a similar whether they are educated or not, from rural or urban territory, from high or low class with less or more contrasts. They are defenceless before men's tricks and they even don't have the full fortitude to defeat any unjustifiable norms. In addition, they have to curb their emotions which affects theirs decision as they have to continue deferring their choice. As indicated by the social standards, man ought to be strong leader, don't tune into his woman, and use viciousness to control her. Unwittingly, man does this to be worthy as a man in the power framework. Man consistently regards woman as 'other' and gives her merely the subservient roles. Thus women are way- laidof all their rights with this sick, power wielding mentalityof men. As we see those three women in both the plays where miss Benare and Champa are punished for fulfilling their sexual desires in search of true love and true man while Laxmi too is punished for not being a desirable woman in man-centric 
SMART MOVES JOURNAL IJELLH e-ISSN: 2582-3574 p-ISSN: 2582-4406 VOL. 8, ISSUE 12, DECEMBER 2020

society. All three struggled hard to win a defeated fight, for their existence but led to the life full of plight. 


\section{References}

Tendulkar, Vijay. Collected Plays in Translation. Introduction by SamikBandopadhyay. New Delhi : OUP, 1992

"Women Characters in the Plays of Vijay Tendulkar. "New Directions in Indian Drama. New Delhi: Prestige Books, 1994.Print.

Tendulkar on his Own Terms. National School of Drama Theatre, Journal N.1, May 2000. Print.

Chitins, Suma. The concept of violence' - from the book edited by Shirin Kukehedker and Sabiha Al-Issa, Violence against women. New Delhi: Pencraft International, 1998

Sinha, Niroj, Dr. Profile of marital violence: Wife Battering', edited by Niroj Sinha, women and violence. New Delhi: Vikas Publishing House pvt. Ltd, 1989

Tendulkar, Vijay. Collected plays in translation. New Delhi: Oxford UP, 2000.

Arundhati Banerjee. Appendix I — Note on Kamala, Silence! The court is in session,

Sakharam Binder, The Vultures, Encounter in Umbugland. Collected plays in Translation. New Delhi: Oxford University Press, 2003

Banerjee, Arundhati. "Introduction," Five Plays, New Delhi; Oxford India Paperbacks, 1995, Eight Impression, 2006.

Tendulkar, Vijay. Silence! The court is in Session, trans. Priya Adarkar, Calcutta: Oxford University Press, 1978

de Beauvoir, Simone. The Second Sex. Trans. H. M. Parshley. New York: Alfred A Knoff, 1976. Print.

Renuka, E. "Casanova as the Saviour : A Study of Vijay Tendulkar's Sakharam Binder". Sudhakar Pandey and Freya Barua (eds.). New Directions in Indian Drama. New Delhi: Prestige, 1994, 33. 